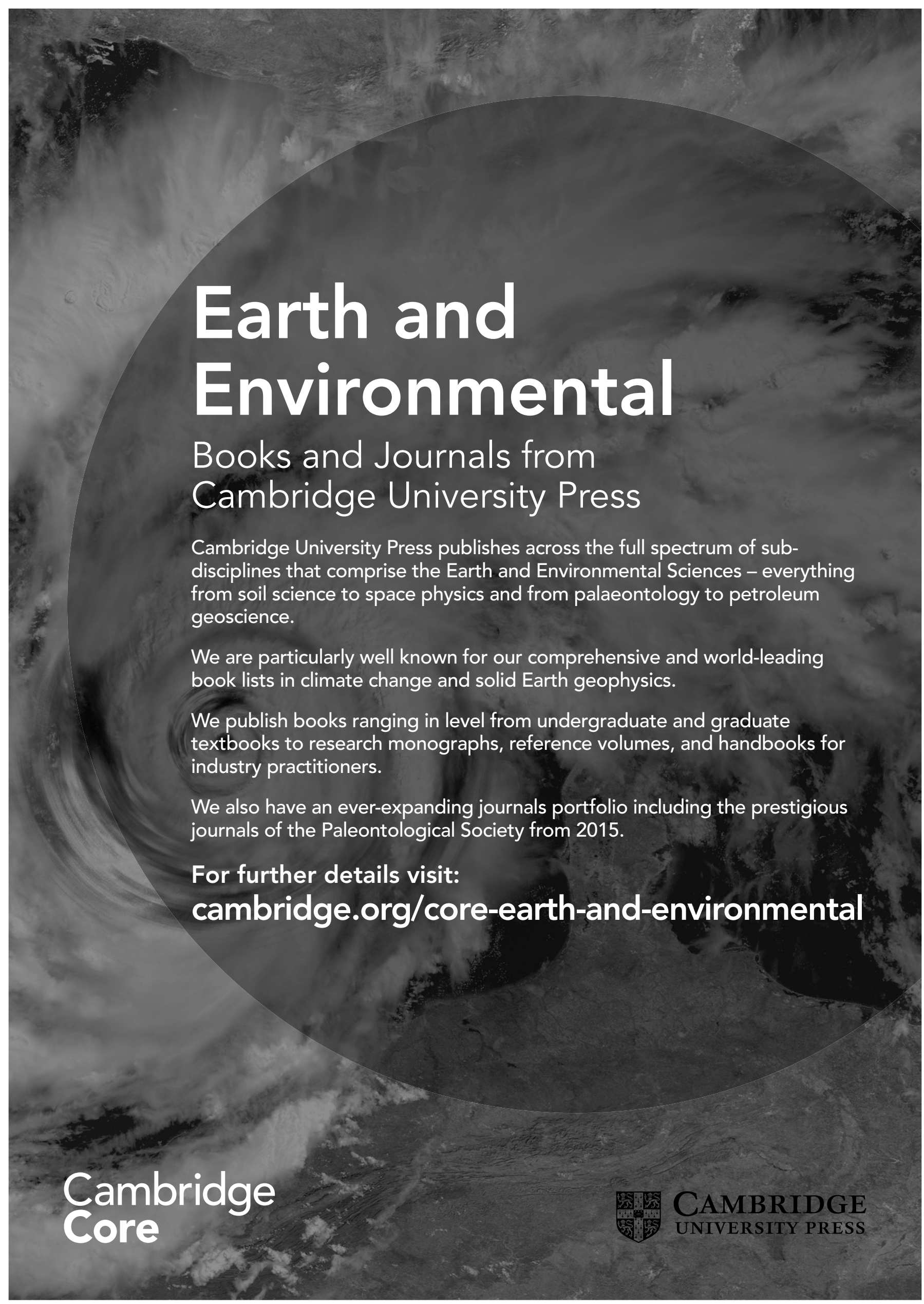




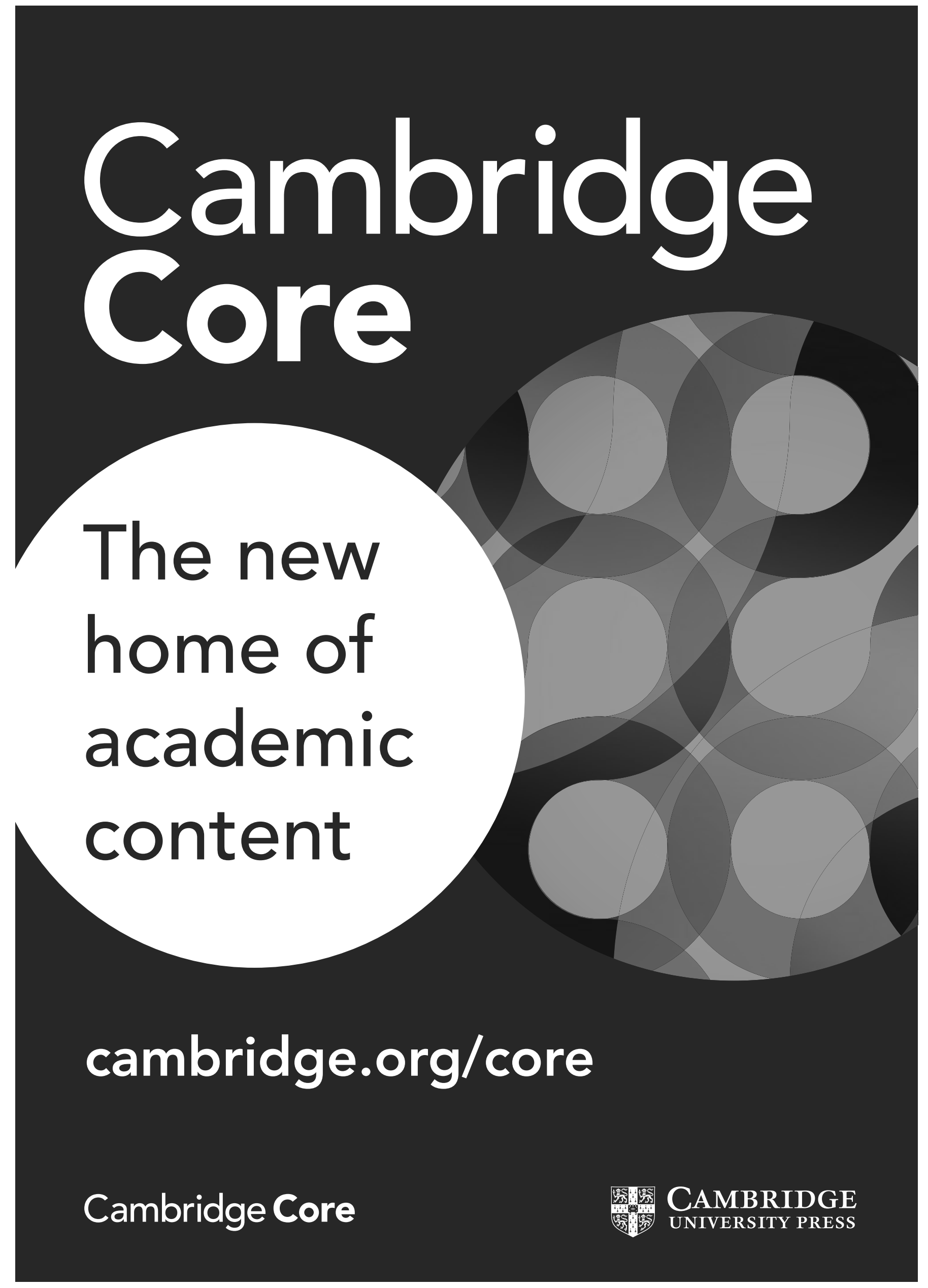




\section{Advisory Board}

H. Brinkhuis, Laboratory of Palaeobotany and Palynology, Dept of Earth Sciences, Utrecht University, Budapestlaan 4, 3584 CD Utrecht, the Netherlands. Also at: Royal Netherlands Institute for Sea Research NI0Z, P.0. Box 59, 1790 AB Den Burg, Texel, the Netherlands

S.A.P.L. Cloetingh, Tectonics Group, Dept of Earth Sciences, Utrecht University, Budapestlaan 4, 3584CD Utrecht, the Netherlands

G. de Lange, Geochemistry Group, Dept of Earth Sciences, Utrecht University, Budapestlaan 4, 3584 CD Utrecht, the Netherlands Ph. Gibbard, Department of Geography, University of Cambridge, Downing Place, Cambridge CB2 3EN, United Kingdom

H. Middelkoop, Global Change Geomorphology Group, Dept Physical Geography, Utrecht University, P.0. Box 80015, 3508 TC Utrecht, the Netherlands

H. Renssen, Earth and Climate Cluster, Dept of Earth Sciences, VU University Amsterdam, De Boelelaan 1085, 1081 HV Amsterdam, the Netherlands

J. Rose, Department of Geography, Royal Holloway University of London, Egham, Surrey TW20 0EX, United Kingdom

J. B. Stuut, Royal Netherlands Institute for Sea Research NIOZ, P.0. Box 59, 1790 AB Den Burg, Texel, the Netherlands

N. Vandenberghe, Institute of Earth Sciences, Leuven University, Redingenstraat 16bis, B-3000 Leuven, Belgium

B. van Geel, Institute for Biodiversity and Ecosystem Dynamics, Department of Palaeoecology and Landscape Ecology, University of Amsterdam, Science Park 904,1098 XH Amsterdam, the Netherlands.

M.J. van der Meulen, TNO - Geological Survey of the Netherlands, P.0. Box 80015, 3508 TA Utrecht, the Netherlands

\section{Editorial Board}

See http://journals.cambridge.org/NJG

\section{Access to NJG online}

From 2014, Netherlands Journal of Geosciences is published online at http://journals.cambridge.org/NJG Volumes 79 - 87 (2000 - 2008$)$ are free to all Core users. In addition, online subscribers have access from Volume 88 (2009) onwards.

\section{Copyright}

(- Stichting Netherlands Journal of Geosciences.

\section{Copying}

This journal is registered with the Copyright Clearance Center, 222 Rosewood Drive, Danvers, MA 01923,USA (www.copyright.com). Organizations in the USA who are also registered with CCC may therefore copy material (beyond the limits permitted by sections 107 and 108 of US copyright law) subject to payment to CCC. This consent does not extend to multiple copying for promotional or commercial purposes. ISI Tear Sheet Service, 3501 Market Street, Philadelphia, PA 19104, USA, is authorized to supply single copies of separate articles for private use only. Organizations authorized by the Copyright Licensing Agency may also copy material subject to the usual conditions. For all other use, permission should be sought from Cambridge University Press.

Cover Image: November 2007 storm surge eroding the western Netherlands coastal dunes near Bergen aan Zee. During the surge event, the foredune was forced back almost $10 \mathrm{~m}$. This revealed a thick sedimentary archive showing evidence of Holocene coastal processes and events. Photo by: Marcel Bakker, TNO - Geological Survey of the Netherlands. 


\section{Netherlands Seologie Journal of ${ }^{\text {Minnouw }}$ Geosciences}

\section{Contents Volume 96, Issue 1}

March 2017

Editorial

Ronald van Balen \& Johan ten Veen

A specimen of Canis cf. C. etruscus (Mammalia, Carnivora) from the Middle Villafranchian of the Oosterschelde

J.W.F. Reumer \& P. Piskoulis

Are Medieval Mya arenaria (Mollusca; Bivalvia) in the Netherlands also clams before Columbus?

K. Essink, A.P. Oost, H.J. Streurman \& J. Van der Plicht

Formation, vegetation succession and acidification of a Mid-Holocene moorland pool in the western Netherlands

B. van Geel, 0. Brinkkemper, E.J. Weeda \& J. Sevink

Stable isotopes, niche partitioning and the paucity of elasmosaur remains in the Maastrichtian type area Anne S. Schulp, Renée Janssen, Remy R. van Baal, John W.M. Jagt, Eric W.A. Mulder \& Hubert B. Vonhof

Holocene landscape evolution of an estuarine wetland in relation to its human occupation and exploitation: Waasland Scheldt polders, northern Belgium

T. Missiaen, I. Jongepier, K. Heirman, T. Soens, V. Gelorini, J. Verniers, J. Verhegge

\& Ph. Crombé

A possible Pararcus diepenbroeki vertebra from the Vossenveld Formation (Triassic, Anisian), Winterswijk, the Netherlands

M.A.D. During, D.F.A.E. Voeten, A.S. Schulp \& J.W.F. Reumer 